Environmental

Biotechnology

\title{
MICROBIAL DIVERSITY IN HEAVY-METAL POLLUTED WATERS
}

\author{
G. Satchanska ${ }^{1}$, E.N. Pentcheva², R. Atanasova²., V. Groudeva ${ }^{3}$, R Trifonova ${ }^{3}$, \\ E. Golovinsky ${ }^{1}$ \\ Institute of Molecular Biology, Bulgarian Academy of Sciences, Sofia, Bulgaria ${ }^{1}$ \\ Geological Institute, Bulgarian Academy of Sciences, Sofia, Bulgaria² \\ Sofia University “St. Kliment Ohridsky”, Faculty of Biology, Sofia, Bulgaria ${ }^{3}$
}

\begin{abstract}
Indigenious water microflora as well as the presence of metal- and xenobiotic biotransforming bacteria were investigated in waters near the KCM Pb-Zn smelter, South Bulgaria. Content of $\mathrm{As}, \mathrm{Hg}, \mathrm{Cd}, \mathrm{Mn}, \mathrm{Pb}, \mathrm{Cu}$ and $\mathrm{Zn}$ exceeded in times the maximum permission standart. Absence of some microbial groups demonstrated a change in the microbial community structure in the region. Ecotoxicology test ISO/DIS 10712.2 displayed toxic environmental effect of the polluted waters, especially one of them which demonstrated 72 $\%$ ofn ecotoxicity. More than 20 ecologically relevant new bacteria were cultured. Three of them demonstrated tolerance to $\mathrm{Cd}, \mathrm{Cu}$ and $\mathrm{Mn}$ and five- a tolerance to 2,4-dichlorphenoxyacetic acid. Our result revealed that the heavy metal pollutions reduced the microbial diversity in the studied waters, are ecotoxic as well as that some of newly isolated bacteria possess a capacity for a clean-up biotechnologies in the region.
\end{abstract}

\section{Introduction}

Microbial-metal transformations represent a key component to metal cycling in natural systems $(14,22)$. Metal transformations in the environment are dominated by redox reactions, complexation of organic and inorganic compounds and cycling among soluble and insoluble forms (3). Moreover bacterial cells living in extreme metal concentrations possess an essential for their survival ability to resist such stress $(5,19)$ The ability of microorganisms to grow in the presence of high metal concentrations results from specific mechanisms as: extracellular precipitation and exclusion of metal ions, binding of the metal ions to the outer surface of bacteria and its intracellular sequestration. Binding of metal cations on the surface of bacterial cells has become one of the most attractive means for metal biotranformation. Those metals which possess electron configurations containing 10 to 12 outer-shell electrons are often toxic to organisms at relatively low concentrations. This group of metals include $\mathrm{Hg}^{2+}, \mathrm{Ag}^{+}$, $\mathrm{Cu}^{+}, \mathrm{Cd}^{2+}, \mathrm{Zn}^{2+}$ and $\mathrm{Pb}^{2+}$ (18). At higher concentrations heavy-metal ions form unspecific complexes in the cell, which lead to toxic effects for human health (20). Metal-microbe interactions have an important role in several biotechnological applications including biomineralization, bioremediation, bioleaching and microbial corrosion and have gained growing attention in recent years (10). This development include the use of indigenious isolates as pure cultures or microbial consortia that are capable to mobilize and immobilize metal ions. Extremely difficult for bioremediation are the co-contaminated with metals and pesticides environments. Phenolic pesticides are hazardous and exhibit acute or chronic toxicity (23). Several genetic mechanisms may contribute to the adaptive response of bacteria to them (27). The problem of pollution with mixed wastes, 
especially environments co-contaminated with metals and pesticides, requires isolation of strains that have metal- and hydrocarbon biotransforming capabilities $(8,12$, 26).

Therefore a major goal of environmental biotechnology is to establish a highly efficient biological processes that use naturally existing catabolic potential for the elimination and detoxification of hazardous chemicals.

The aim of the present work was to derive information about the values of the metal pollution in waters collected near KCM (Kombine of coloured metals), to investigate the effect of pollutants on the microbial community structure as well as their ecotoxicology. In addition to isolate and characterize novel bacterial cultures from the polluted waters and to select the most metal- and pesticides tolerant of them.

\section{Materials and Methods}

\section{Site history and water sampling}

The investigations were carried out in the region with strong industrial activity in South Bulgaria where the KCM-S.A and "AGRIA" plants are located. KCM-S.A. is the biggest lead-zinc smelter in Bulgaria. Its activity started in 1961 and now produce 56,000 t/y of zinc, 48,000 t/y of lead, some precious metals and their alloys. "AGRIA" is a factory for producing of agrochemicals for plant protection. with output sheet including more than 40 herbicides, fungicides and insecticides. Both enterprises have been working for decades and cause a co-contamination with heavy metals and pesticides of soils and waters in the area.

Out of 30 water monitoring points were pre-selected three highly contaminated water samples. Water samples were collected in March 2002 near the KCM factory (see Fig. 1)

Sample No1 is a groundwater, taken from a borehole at $6 \mathrm{~m}$ depth; sample No 2a water from the industrial wastewater

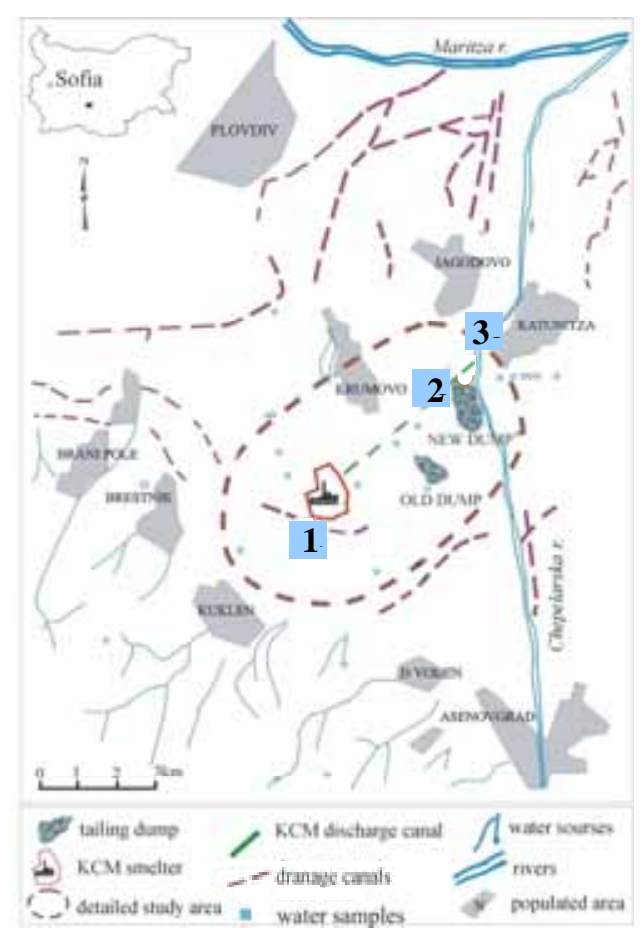

Fig. 1. Location of water samples. ground water; 2industrial wastewater; 3- surfacewater from Chepelarska river.

channel of KCM, which flow in Chepelarska river and sample No 3 is a surface water from Chepelarska river, taken exactly after the influx of both wastewater channels of KCM and AGRIA factories.

The samples were collected in sterile conditions, transported in ice to the laboratory and kept in refrigerator at $4{ }^{\circ} \mathrm{C}$. The analyses started not later than $24 \mathrm{~h}$ after collecting.

\section{Metal-content analysis}

The presence of following elements $\mathrm{Ag}$, $\mathrm{Al}$, As, Ba, Be, Bi, Ca, Cd, Co, Cr, Cu, Fe, Ga, Hg, In, K, Li, Mg, Mo, Na, Ni, Pb, Se, Si, Sn, Sr, Te, Ti, Tl, U, V and Zn was investigated (21). The analyses were carried out by HR-ICP-AES Jobin Yvon ULTIMA 2 (France), in conformity with ISO 11885.

Microbial community structure analysis

Count of viable microbial cells was deter- 
mined by the plate- or liquid media count methods. Using $10 \mathrm{ml}$ of polluted waters a serial dilutions were prepared and spread on selective agar plates and further cultivated for 2,5 and 7 days at 30 or $37^{\circ} \mathrm{C}$. The amount of the following bacteria was analysed: heterotrophic aerobs, heterophic anaerobs, sporeforming bacteria, denitrifying bacteria, amonifying bacteria, nitrifying bacteria, Fe(II)-oxidizing bacteria, Mn(II)-oxidazing bacteria, Fe(III)-reducing bacteria, Mn(IV)-reducing bacteria, colourless sulphur bacteria, Acidithiobacillus thiooxidans, Acidithiobacillus ferrooxidans, Acidithiobacillus denitrificans, Acidithiobacillus thioparus, cellulose degradating bacteria, oligocarbophiles, actinomicetes and fungi $(1,2,4,13,16,25)$. All chemicals used in the analysis were delivered from MERCK and FLUKA (Germany). Nutrient media were supplied by DIFCO (USA).

\section{Isolation of novel bacteria}

Bacterial cultures were isolated at the endpoint serial dilution of agar plates The isolation of microorganisms was carried out by methods described elsewhere (11). The criterion of selectivity of novel bacteria was their colony morphology. Novel heterotrophic aerobes were named $\mathrm{R}$ and the sporeforming isolates- RG). All of them were maintained at $4{ }^{\circ} \mathrm{C}$ and stored in glycerol at $-20^{\circ} \mathrm{C}$ for further investigation.

\section{Ecotoxicology test}

The ecotoxicological test was performed according the ISO/DIS 10712.2: International Standart test method for determining the inhibitory effect of surface, ground and waste water on Pseudomonas putida DSM 50026: (1995) (9). $1 \mathrm{ml}$ of mid-exponential phase $P$. putida was mixed with $5 \mathrm{~mL}$ of each water sample and $4 \mathrm{~mL}$ minimal medium and further cultivated for $16 \mathrm{~h} / 22{ }^{\circ} \mathrm{C} / 180 \mathrm{rpm}$. In the control instead of contaminated water an equivalent volume of mineral medium was added. Each sample was analysed spectrophotometrically at $450 \mathrm{~nm}$ using Specol 11 (Carl
Zeiss, Jena). Minimal medium contained for precultrure $1 \mathrm{~g} \mathrm{NaNO}_{3}, 0.24 \mathrm{~g} \mathrm{~K}_{2} \mathrm{HPO}_{4}$, $0,12 \mathrm{~g} \mathrm{KH}_{2} \mathrm{PO}_{4}, 0.1 \mathrm{~g}$ yeast extract, $10 \mathrm{~g}$ glucose, $0.4 \mathrm{~g} \mathrm{MgSO}_{4}, 0.0001 \mathrm{~g}$ Fe citrat in

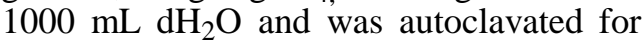
$20 \mathrm{~min}$ at $0.5 \mathrm{~atm}$. For the test culture the yeast extract and glucose were eliminated according to the ISO protocol.

\section{Tolerance to heavy metals and 2,4-D}

The novel bacterial cultures were tested for tolerance towards the most dangerous for the environment and the human health metallic cations and the herbicide 2,4-dichlorphenoxiacetic acid (2,4-D). Stock solutions of metals were prepared in distilled water from salts $\mathrm{CuSO}_{4}, \mathrm{ZnSO}_{4}, \mathrm{~Pb}\left(\mathrm{NO}_{3}\right)_{2}$, $\mathrm{MnSO}_{4}, \mathrm{CdCl}_{2}(\mathrm{MERCK})$ and were sterilized at $0,8 \mathrm{~atm} / 20 \mathrm{~min}$ (7). Bacterial isolates were grown at $30{ }^{\circ} \mathrm{C}$ in presence of above mentioned metals and counted at $24 \mathrm{~h}, 48 \mathrm{~h}$ and $72 \mathrm{~h} \mathrm{C}$. The final metal concentrations were $1 \mathrm{mM} \mathrm{CuSO} 4,1 \mathrm{mM} \mathrm{ZnSO}_{4}, 4 \mathrm{mM}$ $\mathrm{Pb}\left(\mathrm{NO}_{3}\right)_{2}, \quad 20 \mathrm{MM} \mathrm{MnSO}_{4}$ and $0,5 \mathrm{mM}$ $\mathrm{CdCl}_{2}$. The minimal medium was prepared according to ISO protocol as above described. The isolated bacterial cultures were also tested for tolerance to the chlorphenolic herbicide 2,4-dichlorphenoxiacetic acid $\left(\mathrm{C}_{8} \mathrm{H}_{6} \mathrm{Cl}_{2} \mathrm{O}_{3}\right)(\mathrm{MERCK}) .2,4-\mathrm{D}$ is a poorly degradable and third worldwide distributed herbicide and defoliant. Bacteria were grown in mineral medium medium containing per liter $1 \mathrm{~g} \mathrm{NaNO}_{3}, 0.24 \mathrm{~g}$ $\mathrm{K}_{2} \mathrm{HPO}_{4}, 0,12$ g $\mathrm{KH}_{2} \mathrm{PO}_{4}, 0.1$ g yeast extract, $10 \mathrm{~g}$ glucose, $0.4 \mathrm{~g} \mathrm{MgSO}_{4}, 0.0001 \mathrm{~g}$ Fe citrat, with $0.1 \mathrm{mM}$ and $1 \mathrm{mM}$ 2,4-D added with $0.1 \mathrm{mM}$ and $1 \mathrm{mM} 2,4-\mathrm{D}$ added. The cultivation of bacteria was performed for $48 \mathrm{~h}$ at $30^{\circ} \mathrm{C}$.

\section{Results and Discussion}

The metal-content analysis of all waters demonstrated pollution with As, $\mathrm{Hg}, \mathrm{Cd}$, $\mathrm{Mn}, \mathrm{Pb}, \mathrm{Cu}$ and $\mathrm{Zn}$. The amount of these elements is significant in waste and river waters (see Table 1). As the high metal content in industrial wastewater is regular, the probable reason for the strong pollution 
Metal content in waters near KCM-AGRIA (mg/l)

\begin{tabular}{|c|c|c|c|c|c|c|c|}
\hline Sample & As & Hg & Cd & Mn & Pb & Cu & Zn \\
\hline No 1 & 0.148 & 0.069 & 0.136 & 0.140 & $\mathbf{0 . 6 8 3}$ & 0.742 & 1.46 \\
\hline No 2 & 0.018 & 0.004 & $\mathbf{1 . 5 9 7} *$ & $\mathbf{2 . 1 7 5}$ & $\mathbf{1 . 4 7}$ & 0.09 & $\mathbf{5 8 . 2 2}$ \\
\hline No 3 & 0.013 & 0.023 & $\mathbf{1 . 5 3 8}$ & 1.714 & 0.144 & 0.01 & $\mathbf{3 3 . 2 9}$ \\
\hline
\end{tabular}

* Bold numerals show the values exceeding maximum permission limit.

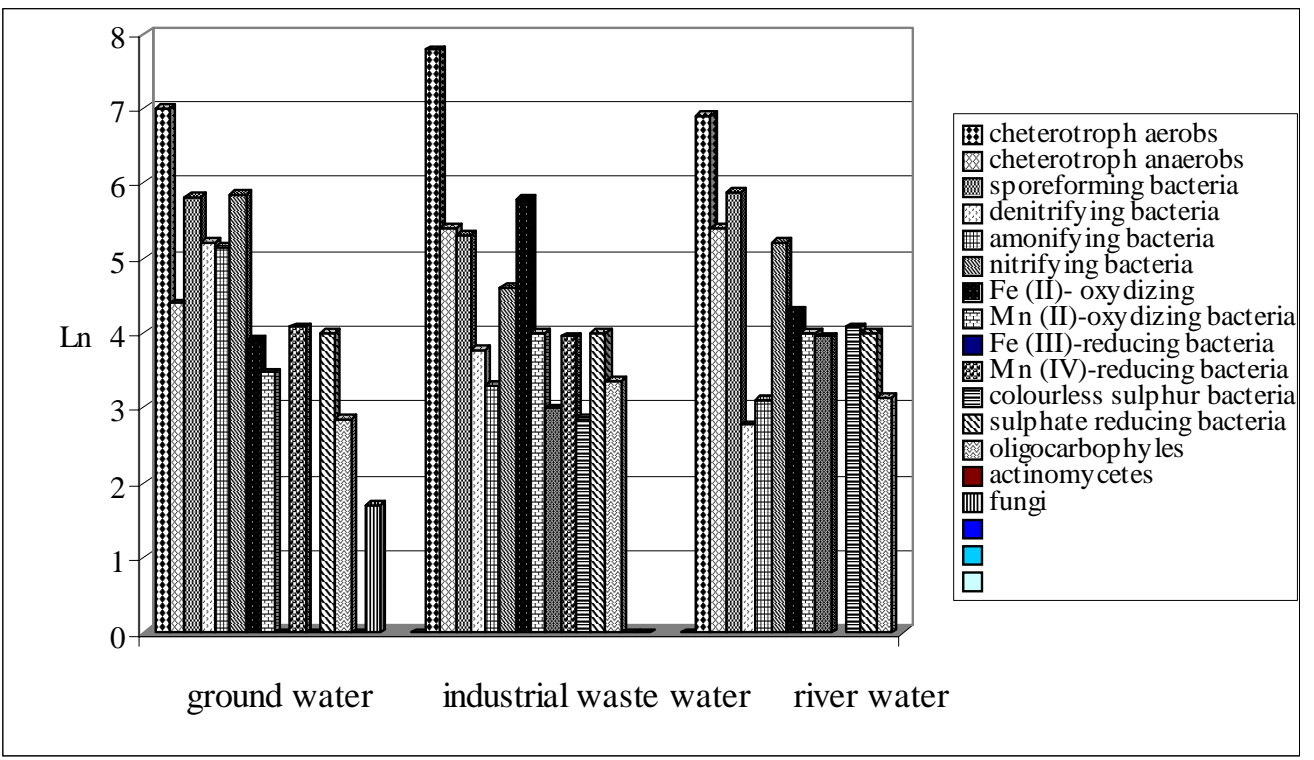

Fig. 2. Quantitative analysis of microbial community in KCM-AGRIA waters.

of river water if the flow of wastewaters from both factories. The amount of the remaining studied metals did not exedded the maximum permission standart. The experimental data concerning chemical species showed a prevalence of the simple cationic forms of the metals. An indisputable pollution with mobile metals and As was registered in the region while the arsenic was also registered in the ground water and could further pollute the drinking water.

The strong metal contaminations influenced the microbial community structure in studied waters. The amount of some bacteria was detected to be reduced and some microbial groups absent at all.

The quantitative microbial analyses exhibited a pronounced prevalence of che- terotrophic aerobes in investigated waters: $10^{8}$ cells/ml for industrial wastewater and $10^{7}$ cells/ml for ground- and river waters. These bacteria require organic supplement for growth. Among this bacteria are the members of genus Bacillus and Pseudomonas, recognized as the most successful one in the metal solubilization (see Fig. 2).

The group of sporeforming bacteria was found with $10^{5}$ cells $/ \mathrm{ml}$ for all three samples. The high number of sporeforming bacteria is indicative for an extreme environment.

Denitrifying, amonifying and nitrifying bacteria showed concentrations of $10^{5}$ cells $/ \mathrm{ml}$ in groundwater and between $10^{2}$ and $10^{5}$ cells/ml in waste- and river waters. 
Amonifying bacteria are chiefly responsible for the mineralization of proteins to the accessible for plants nitrogen. Under the action of nitrifying bacteria $\mathrm{NH}_{3}$ obtained during amonification oxidize to nitrates. The reduction of nitrates to nitrites, ammonia and molecular oxygen is performing by denitrifying bacteria. These bacterial groups form an important part of bacterial community as an indicator for environmental change.

The presence of metal-transforming bacteria was also studied. Mn(II)- and Fe(II)oxidizing bacteria of genus Leptotrix were presented in all samples with level of $10^{4}$ $10^{5}$ cells $/ \mathrm{ml}$. Recent research on the dissimilatory metal-reducing microorganisms has focused on their role in bioremediation of metal-polluted subsurface environments (15). These microorganisms consume the small amount of oxygen typically available in ground water and develop anoxic conditions. Fe(III)-reducing microorganisms degrade organic pollutants within contaminated aquifers and convert U(VI) to U(IV). $\mathrm{Fe}(\mathrm{III})$-reducing bacteria absent in the groundwater but were found in waste and river waters at concentration of $10^{4}$ cells/ml. Mn(IV)-reducing bacteria were detected in samles 1 and 2 but not in the sample 3.

Sulphate reducing bacteria (SRB) which reduce sulphate to hydrogen sulphide in anaerobic conditions and mediate the precipitation of toxic metals as As(V), Cr(VI), $\mathrm{Tc}(\mathrm{VI})$ and $\mathrm{U}(\mathrm{VI})$. SRB were detected in equal amount- $10^{4}$ cells $/ \mathrm{ml}$ in all investigated waters.

Colourless sulphur bacteria are unified in three genera Beggiatoa, Thioploca and Thiotrix. Their amount was found to be $10^{4}$ cells $/ \mathrm{ml}$ in all water samples.

Cellulose degrading bacteria and oligocarbophiles displayed amount of $10^{2}-10^{3}$ cells/ml.

Actinomycetes participate the decomposition of plant's and animal's scrap. No representative of them was detected in any water sample.

Microscopic fungi are able to leach metal cations from solid wastes. Some of them produce organic acids which can solubilize and complex metal cations. Fungi were also not detected in any of waters.(see Fig. 2). As actinomycetes and fungi appear also as an indicator for environmental pollution their absence demonstrated a change in the microbial community structure in the examined waters.

The most active in bioleaching bacteria of genus Acidithiobacillus were subject of special investigation. These bacteria are Gram-negative, non-sporeforming rods growing under aerobic conditions. Most thiobacilli are chemolithoautotrophic species which use the carbon dioxide from the atmosphere as their carbon source for the synthesis of new cell material (29). The energy derives from the oxidation reduced sulphur compounds as final oxidation product- sulphate $(6,17)$. Acidithiobacillus thiooxidans and Acidithiobacillus denitrificans were poorly presented in all waters with $10^{2}-10^{3}$ cells $/ \mathrm{ml}$.

Acidithiobacillus novelus and Acidithiobacillus thioparus were found only in groundwater at concentration $10^{4}$ cells $/ \mathrm{ml}$.

The problem of pollution with mixed wastes, especially of environments cocontaminated with both metals and herbicides, requires isolation of strains that are both metal-resitant and possess herbicide degradative capability. Total of 18 novel indigenious bacterial isolates were investigated for heavy metal resistance. Results revealed that three of them demonstrate metal resistance. Data are shown in Table 2.

All novel bacterial isolates were also screened for herbicide-resistance to 2,4dichlorphenoxyacetic acid.. Isolates $\mathrm{R}_{5}$, $\mathrm{R}_{10}$ and $\mathrm{RG}_{10}$ exibited a tolerance to $1 \mathrm{mM}$ 2,4-D.

Ecotoxicological test (ISO 10712) displayed that all three water samples inhibit in different extent the growth of the type strain Pseudomonas putida DSM 50026. 
Metal tolerance of novel bacterial cultures

\begin{tabular}{|c|c|c|}
\hline Novel isolate & Sample & Tolerance \\
\hline $\mathrm{R}_{6}{ }^{*}$ & 2 & $0.5 \mathrm{mM} \mathrm{CdCl}_{2}$ \\
\hline $\mathrm{RG}_{1}{ }^{* *}$ & 1 & $20 \mathrm{mM} \mathrm{MnSO}_{4}$ \\
\hline $\mathrm{RG}_{7}$ & 1 & $20 \mathrm{mM} \mathrm{MnSO}_{4}$ \\
\hline
\end{tabular}

* cheterotrophic aerob; **sporeforming bacteria

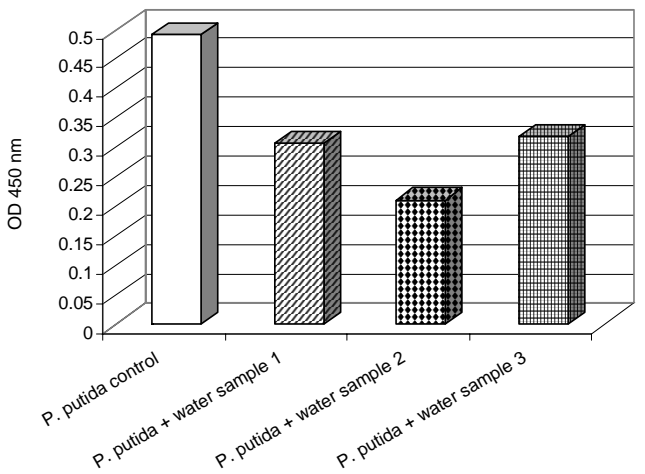

Fig. 3. Ecotoxicology test- ISO/DIS 10712.2.

The industrial wastewater (sample 2) demonstrate the greatest inhibition effect$72 \%$, while the groundwater (sample 1) and river water (sample 3 ) inhibited the growth of this strain at $46 \%$ and $44 \%$ respectively (see Fig. 3).

\section{Conclusions}

Our results suggest that the microbial community responds to long term As, Hg, $\mathrm{Cd}, \mathrm{Mn}, \mathrm{Pb}, \mathrm{Cu}$ and $\mathrm{Zn}$ contamination trough changes in microbial community structure and selection of tolerance. In some of waters was found absence of sulphur-, Fe- and Mn reducing bacteria as well as actinomycetes and fungi. All investigated waters manifest ecotoxicity. Three of the novel bacterial cultures display tolerance to heavy metals- $\mathrm{R}_{6}$ - to $\mathrm{Cd}, \mathrm{RG}_{7}$ - to $\mathrm{Cu}$ and $\mathrm{RG}_{1}$ - to $\mathrm{Mn}$. Three of the isolates demonstrated 2,4- D tolerance. Further the biotransformation capacity of some novel bacteria will be investigated with perspective for their application in a clean-up bio- technologies in the region.

\section{Acknowlegements}

This work was partially granted from project NATO SfP-973739.

\section{REFERENCES}

1. Chang Y., Peacock A., Long P., Stephen J., McKinley J., Macnaughton S., Hussain A., Saxton A., White D. (2001) Appl. Environ. Microbiol., 67, 3149-3160.

2. Dojka M., Hugenholtz P., Haak S., Pace N. (1998) Appl. Environ. Microbiology, 64, 3869-3877.

3. Ehrlich H. (1997) Appl. Microbiol. Biotechnol., 48, 687-692.

4. Fortin D., Roy M., Rioux J., Thibault P. (2000) FEMS Microbiol. Ecol., 33, 197-208.

5. Gadd G. (1988) "Accumulation of metals by microorganisms and algae", In: Biotechnology. (H.J. Rehm, Ed.), Veinheim, 401-433.

6. Groudev S., Groudeva V. (1993) Micriobiol. Rev., 11, 261-268.

7. Hassen A., Saidi N., Cherif M., Boudabous A. (1998) Bioresource Technology, 64, 7-15.

8. Hill R., Ezeani C., Amund O. (2003) American Society of Microbiology; 103-rd General Meeting, May, Washington.

9. ISO/DIS 10712.2 (1995) "Water quality- Pseudomonas putida growth inhibition test (Pseudomonas cell multiplication inhibition test).

10. Joerger K., Joerger R., Olsson E., Granqvist C-G. (2001) TRENDS in Biotechnology, 19, 15-20.

11. Karavaiko G., Rossi G., Agate A., Groudev S., Avakyan Z. (1988) Biogeotechnology of Metals. Manual. Centre for International Projects GKNT, Moscow. (G.I. Karavaiko, Ed.).

12. Leach I., Lewis T. (2003) American Society of Microbiology; 103-rd General Meeting, May, Washington.

13. Leduc L., Ferroni G., Trevors J. (1997) World J. Microbiol. Biotechnol., 13, 453-455.

14. Lloyd J., Lovley D. (2001) Curr. Opin. Biotechn., 12, 248-253.

15. Lovley D. (2002) Features, 68, 231-237.

16. Luef E., Prey T., Kubicek C. (1991), Appl. Microb. Biotechnol., 34, 688-692.

17. Merroun M., Selenska-Pobell S. (2001) Biometals, 14, 171-179.

18. Moore C., DiChristina T. (2002) In: Environmental Microbiology Enciclopedia. (Gabriel Bitton, Ed.) John Wiley\&Sons, Inc.

19. Nakajima A., Sakaguchi T. (1986) Appl. Envi- 
ron. Biotechnol., 24, 59-64.

20. Nies D. (1999) Appl. Microbiol. Biotechnol., 51, 730-750.

21. Pencheva E.N., Velitchkova N., Benderev A., Van't dack L. (2003) "Soluble chemical species of heavy metal pollutants in waters (Plovdiv Region, Bulgaria)”, IOC- UNESCO. (N. Cagatay, Ed.).

22. Rawlings D., Silver S. (1995) BioTechnology, 13, 773-778.

23. Rieger P-G., Meier H-M., Gerle M., Vogt U., Groth T., Knackmuss H-J. (2002) J. Biotechnology, 94, 101-123.

24. Selenska-Pobell S., Kampf G., Flemming K., Radeva G., Satchanska G. (2001) Antonie van
Leewenhoek, 79, 146-161.

25. Silver S., Phung, L. (1996) Ann. Rev. Microbiol., 50, 753-789.

26. Topalova Y., Petrova K. (1995) In: Bioremediation of Recalcitrant Organic, (R.E. Hinchee, R. Hoepel, D. Anderson, Eds.), Battle Press-3(7), 217224.

27. van der Meer R., de Vos W., Harayama S., Zendler A. (1992) Microbiol. Rev., 56, 677-694.

28. Stephen J., Chang Y-J., Macnaughton S., Kowalchuk G., Leung K., Flemming C., White D. (1999) Appl. Environ. Microbiology, 65, 95-101.

29. Boseker K. (1997) FEMS Microbiology Reviews, 20, 591-604. 